\title{
Pengaruh Media Pembelajaran Berbasis Komputer Dengan Model Tutorial Untuk Meningkatkan Hasil Belajar Siswa Pada Mata Pelajaran Tik
}

\author{
Ayu Lestari ${ }^{1}$, Andri Suryadi ${ }^{2}$, Ali Ismail ${ }^{3}$ \\ Pendidikan Teknologi Informasi, Fakultas Ilmu Terapan dan Sains, Institut Pendidikan Indonesia, \\ Jl. Terusan Pahlawan No.32, Garut 44151,Indonesia. \\ lestariayulgmail.com \\ andri.suryadiecampus.ut.ac.id \\ aliismail7@institutpendidikan.ac.id \\ Sistem Informasi, Universitas Terbuka, \\ Jl. Cabe Raya. Pondok Cabe Pamulang. Tangerang Selatan 15418, Banten,Indonesia.
}

\begin{abstract}
Abstact - This study aims to determine the increase in student learning outcomes using computer-based learning media tutorial models. This type of research used in this study is a quasi-experimental study. This quasi-experimental study aims to explain the causal relationship by involving the control group in addition to the experimental group. The population in this study were all students of SMPN 1 Cisurupan. Determination of the sample using a random technique (random), the sample obtained was class VIII-F as a control class with 30 students and VIII-C as an experimental class with 30 students. The research instrument in this study uses multiple choice questions that have been tested for validity, reliability, distinguishing features and difficulty levels. Research Results obtained in this study the comparison of the gain score between the experimental class and the control class is 31.26: 18.67. Meanwhile, the change of Gain transferring the experimental class with the control class is $0.65: 0.35$ and the standard deviation of improvement of student learning outcomes about the experimental class Blog material is 9.93 and the control class is 9.60. It can be concluded that the Computer Based learning model with Tutorial Model can significantly improve student learning outcomes in ICT lessons compared to conventional learning models.
\end{abstract}

Keywords — student learning outcomes, Computer Based Learning, Model Tutorials.

Abstrak-Penelitian ini bertujuan untuk mengetahui peningkatan hasil belajar siswa sesudah menggunakan media pembelajaran berbasis komputer model tutorial. Jenis Penelitian yang digunakan dalam penelitian ini adalah penelitian kuasi eksperimen. Penelitian kuasi eksperimen ini bertujuan untuk mengungkapkan hubungan sebab akibat dengan cara melibatkan kelompok kontrol disamping kelompok eksperimen. Populasi dalam penelitian ini adalah seluruh siswa SMPN 1 Cisurupan. Penentuan sampel menggunakan teknik random (acak), sampel yang diperoleh adalah kelas VIII-F sebagai kelas kontrol dengan jumlah siswa 30 siswa dan VIII-C sebagai kelas eksperimen dengan jumlah siswa 30 siswa. instrumen penelitian dalam penelitian ini menggunakan instrumen soal dengan bentuk pilihan ganda yang sudah di uji validitas, reliabilitas, daya pembeda dan tingkat kesukaran. Hasil Penelitian yang diperoleh dalam penelitian ini yaitu perbandingan Gain skor antara kelas eksperimen dengan kelas kontrol adalah 31,26 : 18,67. Sedangkan, perbandingan Gain ternormalisasi antara kelas eksperimen dengan kelas kontrol adalah 0,65 : 0,35 dan standar deviasi peningkatan hasil belajar siswa mengenai materi Blog kelas eksperimen adalah 9,93 dan kelas kontrol adalah 9,60. Dapat disimpulkan bahwa model pembelajaran Berbasis Komputer dengan Model Tutorial secara signifikan dapat lebih meningkatkan hasil belajar siswa pada pelajaran TIK dibandingkan dengan model pembelajaran konvensional.

Kata Kunci — hasil belajar siswa, media Pembelajaran Berbasis Komputer, Model Tutorial 


\section{PENDAHULUAN}

Tik merupakan salah satu pelajaran yang sangat penting untuk dipelajari. Sudayana [2015] menyatakan bahwa "tik merupakan salah satu komponen dari serangkaian mata pelajaran yang mempunyai peranan penting dalam pendidikan" [1]. Namun pada kenyataannya masih banyak siswa menganggap tik sebagai pelajaran yang sulit, tidak menyenangkan, bahkan membosankan untuk dipelajari. Mata pelajaran tik diberikan pada peserta didik sejak dari sekolah menengah pertama, sekolah menengah atas, hingga perguruan tinggi. Materi dalam tik memiliki keterkaitan antara satu unit dengn unit yang lainnya, oleh karena itu kemampuan seseorang dalam mengkoneksikan antar unit sangat diperlukan dalam memecahkan masalah matematika.

Pembelajaran TIK di sekolah guru masih sering kali hanya menggunakan metode ceramah sehingga proses pembelajaran menjadi membosankan dan tidak menarik padahal isi dari pembelajaran TIK itu sendiri sebenarnya mengasyikkan, penggunaan media dan sarana prasarana penunjang pembelajaran pun dirasa masih sangat minim dalam pembelajaran TIK ini padahal isi dari mata pelajaran TIK ini sangat luas dan kompleks yang membutuhkan sarana belajar yang mendukung, sehingga dirasa tidak cocok jika pembelajaran hanya dilaksanakan dengan metode ceramah semata.

Diperlukan media sebagai sarana untuk guru dalam membelajarkan mata pelajaran TIK ini, agar pembelajaran lebih efektif dan mudah dimengerti oleh siswa. Keterbatasan alat peraga dan seringnya guru meninggalkan jam pelajaran juga menjadi masalah yang sama dalam pelaksanaan pembelajaran TIK yang mengakibatkan proses pembelajaran tidak dapat berjalan lancar, sehingga dibutuhkan adanya media pembelajaran agar proses pembelajaran dapat tetap berlangsung meskipun tanpa kehadiran guru dan keterbatasan alat pembelajaran.

Kemampuan koneksi matematis (mathematical connection) adalah kemampuan dalam mengaitkan konsepkonsep matematika baik antar konsep matematika itu sendiri maupun mengaitkan konsep matematika dengan bidang lain.

Hal lain yang menjadi permasalahan dalam proses pembelajaran TIK ini adalah seringkali mata pelajaran TIK dianggap remeh oleh guru. Sebagian besar guru hanya menganggap penting mata pelajaran yang di UAN kan,sedangkan mata pelajaran TIK ini kurang diperhatikan. Hal-hal tersebut diatas menjadi kendala dalam memahami mata pelajaran TIK, sehingga mempengaruhi pula terhadap rendahnya hasil belajar siswa pada mata pelajaran ini.

Berdasarkan dari permasalahan diatas hasil wawancara peneliti dengan guru mata pelajaran TIK SMP Negeri 1 Cisurupan, diketahui berdasarkan hasil ulangan mata pelajaran TIK pokok bahasan Membuat dokumen pengolah angka sederhana, hasil yang diperoleh siswa belum maksimal, dari 40 siswa yang mengikuti ujian, sebanyak $52 \%$ atau sebanyak 28 siswa masih di bawah standar kompetensi yang diterapkan (KKM Mapel TIK di SMP N 1
Cisurupan adalah 7,0). Hal ini di karenakan masih belum mengerti materi yang yang disampaikan oleh guru. Oleh karena itu dengan adanya pembelajaran berbasis komputer sangat perlu untuk di gunakan pembelajaran. Oleh karena itu pembelajaran di SMPN 1 Cisurupan perlu adanya pembelajaran Alternatif yaitu dengan menggunakan media pembelajaran berbasis komputer dengan model tutorial.

Media pembelajaran berbasis komputer dengan model tutorial yang digunakan dalam penelitian ini berbentuk sebuah tutorial yang dirancang dan dibuat berdasarkan silabus dan tujuan pembelajaran. Media ini dapat disimpan (copy) oleh siswa untuk dipelajari lagi dirumah. Selain itu sistem pembelajaran yang digunakan secara individual melalui komputer memberikan kesempatan kepada siswa untuk mendapatkan pengalaman yang sama dan memberikan kesempatan kepada setiap individu untuk memahami materi pelajaran dengan sebaik-baiknya.

Pembelajaran berbasis komputer merupakan pembelajaran dengan menggunakan software komputer (CD pembelajaran) berupa program komputer yang berisi tentang muatan pembelajaran meliputi: judul, tujuan, materi pembelajaran, dan evaluasi pembelajaran.

Permasalahan lain yang ditemukan di sekolah adalah guru belum mampu memanfaatkan secara maksimal fasilitas yang sudah ada di sekolah mulai dari laptop, LCD proyektor dan sebuah ruang LAB yang sudah disediakan oleh sekolah. Permasalahan yang paling menonjol dalam proses pembelajaran adalah terbatasnya media pembelajaran yang menarik dan kurang efektifnya waktu dalam satu kali pertemuan materi. Penggunaan media yang masih sangat konvensional seperti papan tulis dirasa sudah tidak menarik lagi.

Dengan demikian SMP Negeri 1 Cisurupan masih membutuhkan alternatif media dan model pembelajaran yang dapat membantu penyampaian materi yang bersifat abstrak menjadi kongkrit, tidak hanya dapat membaca, mendengarkan atau hanya melihat gambar pasif saja, tetapi butuh bantuan media secara nyata yang dapat membantu aktifitas proses belajar mengajar terutama peningkatan hasil belajar siswa.

Hamalik (1991:73) (dalam Abi Masiku (2003:10)) mengemukakan bahwa tutorial adalah bimbingan pembelajaran dalam bentuk pemberian bimbingan, bantuan, petunjuk, arahan, dan motivasi agar siswa dapat efisien dan efektif dalam belajar. Subyek atau tenaga yang memberikan bimbingan dalam kegiatan tutorial dikenal sebagai tutor. Tutor dapat berasal dari guru atau pengajar, pelatih, pejabat struktural, atau bahkan siswa yang dipilih dan ditugaskan guru untuk membantu teman-temannya dalam belajar di kelas .

Berdasarkan latar belakang yang diuraikan diatas, maka perumusan masalah yang dibahas dalam program ini adalah sebagai berikut:

1. Bagaimanakah Pengaruh pembelajaran berbasis konvensional terhadap hasil belajar siswa? 
2. Bagaimanakah Pengaruh media pembelajaran berbasis komputer dengan model tutorial terhadap hasil belajar siswa?

3. Bagaimanakah perbandingan hasil belajar siswa kelas VIII yang menggunakan model tutorial dengan pembelajaran berbasis komputer dengan siswa yang menggunakan pembelajaran konvensional?

\section{KAJIAN TEORITIS}

\section{A. Pengertian Pembelajaran}

Menurut Nana Sudjana dan Ahmad Rivai (2002: 1) menyatakan proses belajar mengajar atau proses pengajaran merupakan suatu kegiatan melaksanakan kurikulum suatu lembaga pendidikan, agar dapat mempengaruhi para siswa mencapai tujuan pendidikan yang telah ditetapkan [2].

Pernyataan tersebut diperjelas oleh Daryanto (2010:2) yang menyatakan bahwa menurut paradigma behavioristik, belajar merupakan transmisi pengetahuan dari expert ke novice [3]. Berdasarkan konsep in, peran guru adalah menyediakan dan menuangkan informasi sebanyak-banyaknya kepada siswa. Guru mempersepsi diri berhasil dalam pekerjaannya apabila dia dapat menunagkan pengetahuan sebanyak-banyaknya kepada siswa, dan siswa dipersepsi berhasil apabila mereka tunduk menerima pengetahuan yang dituangkan guru kepada mereka.

Belajar adalah suatu proses yang kompleks yang terjadi pada diri setiap orang sepanjang hidupnya [4]. Batasan diatas dikuatkan sadiman, dkk (2009:2) dalam bukunya yang berjudul media pendidikan mengemukakan belajar adalah suatu proses yang kompleks yang terjadi pada semua orang dan berlangsung seumur hidup, sejak dia masih bayi hingga keliang lahat nanti [5].

\section{B. Media Pembelajaran}

Menurut Daryanto (2010: 4) dalam bukunya yang berjudul Media pembelajaran mengatakan secara umum media merupakan kata-kata jamak dari "medium" yang berarti perantara atau pengantar terjadinya komunikasi dari pengirim menuju penerima. Kata media berlaku untuk berbagai kegiatan atau usaha seperti media dalam penyampaian pesan, media pengantar magnet atau panas dalam bidang teknik. Istilah media juga digunakan dalam bidang pengajar atau pendidikan, sehingga menjadi media pembelajaran atau media pendidik [6].

C. Penggunaan Media Pembelajaran

Salah satu gambaran yang paling banyak dijadikan acuan sebagai landasan teori penggunaan media dalam proses belajar adalaah Dale's Cone of Experience (kerucut pengalaman Dale). Hasil belajar seseorang diperoleh mulai dari pengalaman langsung (kongkret).

D. Media pembelajaran Berbasis Komputer

Seiring perkembangan dunia IT, pemaknaan "multimedia" ini semakin bergeser pada aspek pengintegrasian sistem dan jaringan serta prosedur komunikasi dalam sebuah perangkat khusus seperti televisi, radio, komputer, notebook, netbook.

Deni Darmawan, (2011:32) dalam bukunya yang berjudul Teknologi Pembelajaran memaparkan bahwa pembelajaran interaktif sering dikenal dengan pembelajaran berbasis komputer. Teknologi berbasis komputer merupakan cara menghasilkan atau menyampaikan materi dengan menggunakan sumbersumber yang berbasis micro-prosesor. Berbagai aplikasi teknologi berbasis komputer dalam pembelajaran umumnya dikenal sebagai pandangan nama-nama seperti CAI (Computer Assistance Instruction) dan CBI (Computer Based Instruction). Dengan menggunakan komputer pendidik dapat mengembangkan desain, produksi, implementasi, bahan evaluasi pembelajaran [7]

CAI (Computer Assistance Instruction) yaitu pembelajaran dengan bantuan komputer, komputer hanya sebagai alat bantu, sedangkan CBI (Computer Based Instruction) yaitu sistem pembelajaran berbasis komputer [6]

Benny A, dkk (2002:11-13) mengemukakan beberapa kelebihan yang ada pada pembelajaran berbasis komputer [8]:

1) Komputer memungkinkan siswa belajar sesuai dengan kemampuan dan kecepatannya dalam memahami pengetahuan dan informasi yang ditanyakan.

2) Penggunaan komputer dalam proses belajar membuat siswa dapat melakukan kontrol terhadap aktivitas belajarnya.

3) Penggunaan komputer dalam lembaga pendidikan memberikan keleluasan terhadap siswa untuk menentukan kecepatannya belajar dan memilih urutan kegiatan belajar sesuai dengan kebutuhan.

4) Kemampuan komputer untuk menayangkan kembali informasi yang diperlukan oleh pemakainya, yang diidtilahkan dengan "kesabaran komputer", dapat membantu siswa yang memiliki kecepatan belajar lambat. Dengan kata lain, komputer dapat menciptakan iklim belajar yang efektif bagi siswa yang lambat (slow learner), tetapi juga dapat memacu efektivitas belajar bagi siswa yang lebih cepat (fast learner).

5) Komputer dapat diprogram agar mampu memberikan umpan balik terhadap hasil belajar dan memberikan pengukuran (reinforcement) terhadap prestasi belajar siswa.

6) Komputer dapat diprogram untuk memeriksa dan memberikan skor hasil belajar secara otomatis.

7) Komputer dapat dirancang agar dapat memberikan preskripsi atau saran bagi siswa untuk melakukan kegiatan belajar tertentu. 
8) Kemampuan dalam mengintegrasikan komponen warna, musik dan animasi grafik (grafic animation).

9) Dapat meningkatkan hasil belajar dengan penggunaan waktu dan biaya yang relatif kecil. Contoh yang tepat untuk ini adalah program komputer simulasi untuk melakukan percobaan pada mata kuliah sains dan teknologi. Penggunaan program simulasi dapat mengurangi biaya bahan dan peralatan untuk melakukan percobaan.

Benny A, dkk juga mengemukakan bahwa selain memiliki beberapa kelebihan pembelajaran berbasis komputer juga memiliki beberapa kekurangan yaitu [8] :

1) Tinggnya biaya pengadaan dan pengembangan program komputer, terutama yang dirancang khusus untuk maksud pembelajaran.

2) Pengadaan, pemeliharaan, dan perawatan komputer yang meliputi perangkat keras (hardware) dan perangkat lunak (software) memerlukan biaya yang relatif tinggi. Oleh karena itu pertimbangan biaya dan manfaat perlu dilakukan sebelum memutuskan untuk menggunakan komputer untuk keperluan pendidikan.

3) Compatability dan incompability antara hardware dan software. Penggunaan sebuah program komputer biasanya memerlukan perangkat keras dengan spesifikasi yang sesuai. Perangkat lunak sebuah komputer seringkali tidak dapat digunakan pada komputer yang spesifikasinya tidak sama.

4) Merancang dan memproduksi program pembelajaran yang berbasis komputer (computer based instruction) merupakan pekerjaan yang tidak mudah. Memproduksi program komputer merupakan kegiatan intensif yang memerlukan waktu dan juga keahlian khusus.

Dapat disimpulkan bahwa media pembelajaran berbasis komputer adalah sebuah media pembelajaran yang memanfaatkan komputer sebagai alat untuk mengolah tampilan materi pelajaran menjadi lebih menarik dengan berbagai aplikasi didalamnya. Media pembelajaran berbasis komputer dapat diolah menyesuaikan keadaan dan kebutuhan proses pembelajaran. Selain itu pembelajaran dengan media berbasis komputer juga memiliki banyak kelebihan diantaranya dapat meningkatkan hasil belajar dengan penggunaan waktu dan biaya yang relatif kecil.

Macam macam media pembelajaran berbasis komputer di antaranya :

\section{1) Tutorial}

Format ini digunakan untuk menyajikan materi kepada siswa, komputer meniru guru atau instruktur menyampaikan informasi. Informasi atau Materi yang disajikan berupa teks, gambar bergerak maupun diam dan grafik.

\section{2) Drills and practice}

Format ini berisi latihan untkmemahirkan keterampilan atau memperkuat penguasaan suatu konsep. Penyajian materi dalam bentuk soal-soal atau pertanyaan secara terstruktur dan linier yang harus dijawab oleh pengguna.

3) Simulasi

Format ini memungkinkan siswa untuk berperan serta dalam kejadian-kejadian yang lebih dekat atau mirip dengan dunia nyata, yang sengaja dibuat agar siswa dapat mengambil keputusan. Format yang disajikan dalam bentuk simulasi atau proses terjadinya sesuatu, cara atau prosedur kerja dan mengerjakan sesuatu dengan dan tanpa alat khusus dalam sajian animasi yang lengkap.

4) Permainan Interaktif

Format sajian multi media ini merupakan salah satu cara yang baik untuk memperkenalkan komputer dengan siswa. permainan pada komputer lebih tinggi memberikan motivasi dan meningkatkan pengetahuan serta keterampilan.

Dari keempat macam media berbasis komputer diatas penelitian ini menggunakan kolaborasi antara model tutorial karena dengan adanya keterbatasan waktu serta keterbatasan format media pembelajaran yang dimiliki oleh peneliti, model tutorial ini lebih memungkinkan dalam menyampaikan semua materi yang terdapat pada stndar kompetensi yang telah ditetapkan. Guru bertugas untuk menyampaikan informasi berupa teks, atau gambar bergerak, dan pada waktu yang sama siswa menyerap materi yang disampaikan.

E. Tutorial

Tutorial atau tutoring adalah bantuan atau bimbingan belajar yang bersifat akademik oleh tutor kepada mahasiswa (tutee) untuk membantu kelancaran proses belajar mandiri mahasiswa secara perorangan atau kelompok berkaitan dengan materi ajar. Tutor adalah orang yang memberikan ilmu kepada anak didik secara langsung, mahasiswa lebih memahami konsep dan praktek pendidikan non formal yang lebih baik. Tutorial dilaksanakan secara tatap muka atau jarak jauh berdasarkan konsep belajar mandiri.

Konsep belajar mandiri dalam tutrorial mengandung pengertian, bahwa tutorial merupakan bantuan belajar dalam upaya memicu dan memacu kemandirian, disiplin dan inisiatif diri mahasiswa dalam belajar dengan minimalisasi intervensi dari pihak pembelajar yang dikenal sebagai tutor. Prinsip pokok tutorial adalah "kemandirian mahasiswa" (Student's independency). Tutorial tidak ada, jika kemandirian tidak ada. Jika mahasiswa tidak belajar dirumah, dan datang ke tutorial dengan 'kepala kosong'.

\section{F. Hasil belajar}


Hasil belajar siswa menurut Nana Sudjana (2011: 22) adalah kemampuan-kemampuan yang dimiliki oleh siswa setelah ia menerima pengalaman belajarnya [9]. Sedangkan menurut Tabrani Rusyan, dkk (1994: 79), hasil belajar adalah kebulatan tingkah laku. Perilaku atau tingkah laku mengandung pengertian yang luas mencakup pengetahuan, pemahaman, keterampilan, sikap, dan sebagainya, hal ini dapat didefinisikan, bahkan dapat diukur dari penampilan (behavioral perfomance). Penampilan ini dapat berupa kemampuan menjelaskan, menyebutkan sesuatu, atau melakukan sesuatu kegiatan atau perbuatan [10].

Hasil Belajar adalah sejumlah pengalaman yang diperoleh siswa yang mencakup ranah kognitif, afektif, dan psikomotorik. Gagne mengatakan bahwa segala sesuatu yang diperoleh oleh manusia dapat dibagi menjadi 5 kategori yang disebut "the domains of learning" yaitu: keterampilan motoris (motor skill). Informasi verbal, kemampuan intelektual, strategi kognitif, dan sikap.

Dari uraian diatas dapat disimpulkan bahwa hasil belajar adalah pengetahuan yang dimiliki oleh siswa setelah mengikuti proses belajar mengajar. Hasil belajar biasanya dapat dilihat dari nilai ulangan harian yang dilakukan setelah kompetensi mata pelajaran sudah disampaikan.

Menurut Bloom tujuan pembelajaran dapat diklasifikasikan ke dalam tiga ranah (domain), yaitu [11]:

1) Cognitive Domain (Ranah Kognitif) yang berisi perilaku-perilaku yang menekankan aspek intelektual, seperti pengetahuan, pegertian, dan keterampilan berpikir.

2) Affecitive Domain (Ranah Afektif), berisi perilaku-perilaku yang menekankan aspek perasaan dan emosi, seperti minat, sikap, apresiasi, dan cara penyesuaian diri.

3) Psychomotor Domain (Ranah Psikomotor), berisi perilaku-perilaku-perilaku yang menekankan aspek keterampilan motorik seperti menulis, mengetik, berenang, dan mengoperasikan mesin.

Menurut Bloom ranah kognitif menggolongkan dan mengurutkan keahlian berpikir yang menggambarkan tujuan yang diharapkan. Proses berpikir mengekspresikan tahapn-tahap kemampuan yang harus siswa kuasai, sehingga dapat menunjukan kemampuan mengolah pikirannya sehingga dapat menunjukan kemampuan mengolah pikirannya sehingga mampu mengaplikasikan teori ke dalam perbuatan [11].

Salah satu aspek penilaian yang dilakukan terhadap hasil belajar adalah pada ranah kognitif. Ranah kognitif ini merupakan ranah yang lebih banyak melibatkan kegiatan mental/otak. Pada ranah kognitif terdapat enam jenjang proses berpikir yang disebut dengan Taksonomi Bloom yang direvisi oleh Rin W. Anderson dan David R. Krathwohl [11]. Adapun taksonomi ini antara lain: a) Mengingat (Remember C1)

Jenjang hapalan (ingatan) meliputi kemampuan menyatakan kembali fakta, konsep, prinsip, dan proseduryang telah dipelajarinya.

b) Memahami (Understand C2)

Jenjang pemahaman meliputi kemampuan menangkap arti informasi yang diterima, misalnya dapat menafsirkan bagan, diagram, atau grafik, menerjemahkan suatu pernyataan verbal kedalam rumusan matematis atau sebaliknya, meramalkan berdasarkan kecenderungan tertentu (ekstrapolasi interpolasi), serta mengungkapkan suatu konsep atau prinsip dengan kata-kata sendiri.

c) Menerapkan (application C3)

Yang termasuk jenjang penerapan ialah kemampuan menggunakan prinsip, aturan, metode yang dipelajari pada situasi baru atau pada situasi konkrit.

d) Menganalisis (analysis C4)

Jenjang analisis meliputi kemampuan menguraikan suatu informasi yang dihadapi menjadi komponenkomponennya sehingga struktur informasi serta hubungan antar komponen informasi tersebut menjadi jelas.

e) Mengevaluasi (evaluation C5)

Kemampuan pada jenjang evaluasi ialah kemampuan untuk mempertimbangkan nilai suatu pernyataan, uarian, pekerjaan, berdasarkan kriteria tertentuyang ditetapkan.

f) Menciptakan (create C6)

Satu tingkat di atas evaluasi. Seseorang di tingkat Create akan mampu membuat struktur atau pola dari sebuah skenario yang sebelumnya tidak terlihat, dan mampu mengenali data atau informasi yang harus didapat untuk menghasilkan solusi yang dibutuhkan.

\section{METODOLOGI PENELITIAN}

\section{A. Populasi dan Sampel}

Populasi dalam penelitian ini adalah seluruh siswa kelas VIII SMPN 1 Cisurupan tahun ajaran 2016-2017. Adapun yang dijadikan sampel adalah siswa kelas VIIIC sebagai kelas eksperimen dan kelas VIII-F sebagai kelas kontrol.

\section{B. Waktu dan Tempat Penelitian}

Penelitian ini dilaksanakan di SMPN 1 Cisurupan pada kelas VIII semester 2 tahun ajaran 2016/2017, yaitu pada tanggal 7 April s.d 29 April 2017.

\section{Desain Penelitian}

Desain yang digunakan dalam penelitian ini adalah The Nonequivalent Pretest-Posttest Control Group Design.

TABEL I

NONEQUIVALENT GROUP PRETEST-POSTTES DESIGN 
keterangan :

01 : Pretest (test awal)

02 : Postest (test akhir)

X1 : Perlakuan model pembelajaran berbasis komputer dengan model tutorial

X2 : Perlakuan model pembelajaran konvensional

\section{Teknik Pengumpulan Data dan Analisis Data}

Analisis data dilakukan untuk memberikan gambaran terhadap data yang telah dikumpulkan dari hasil penelitian. Hal ini dimaksudkan untuk mencari kesimpulan dan menguji hipotesis. Data yang dianalisis diperoleh dari hasil pre-test, dan post-test.

\section{HASIL DAN PEMBAHASAN}

A. Deskripsi Data Hasil Penelitian Belajar Siswa Penelitian ini dilaksanakan di SMPN 1 Cisurupan, pada kelas VIII-C (Sebagai kelas eksperimen) dan VIII-F (sebagai kelas kontrol) semester II pada materi microsoft excel (Pengolah Angka). Data hasil belajar TIK siswa disajikan berdasarkan pada tujuan yang telah dirumuskan meliputi nilai pretest dan posttest dari dua kelompok yang berbeda. Kelompok eksperimen dalam pembelajaran menggunakan media pembelajaran berbasis komputer dengan model tutorial sebanyak 30 siswa dan kelompok kontrol dalam pembelajaran menggunakan konvensional sebanyak 30 siswa.

B. Analisis Statistik dan Uji Hipotesis

Hasil Pretes, postes dan peningkatan hasil belajar kelas kontrol.

Pelaksanaan pre-test dilakukan oleh kelas kontrol maupun kelas eksperimen. Pre-test terdiri dari 30 soal pilihan ganda yang harus dikerjakan siswa selama $2 \times 40$ menit. Siswa mengerjakan secara individual dan setelah selesai kemudian dikumpulkan untuk diperiksa. Analisis daa tes awal (pre-test) yang diperoleh dari kelas kontrol dan kelas eksperimen bertujuan untuk mengetahui peningkatan hasil belajar siswa awal pada sebelum diberi perlakuan atau pembelajaran. Selanjutnya untuk mengetahui peningkatan hasil belajar dilakukan dengan menghitung nilai gain ternormalisasi.

\begin{tabular}{|l|c|c|c|}
\hline \multicolumn{1}{|c|}{ Kelompok } & pretes & Perlakuan & Postes \\
\hline E (Exsperimen) & 0 & $\mathrm{X} 1$ & 0 \\
\hline K (Kontrol) & 0 & $\mathrm{X} 2$ & 0 \\
\hline
\end{tabular}

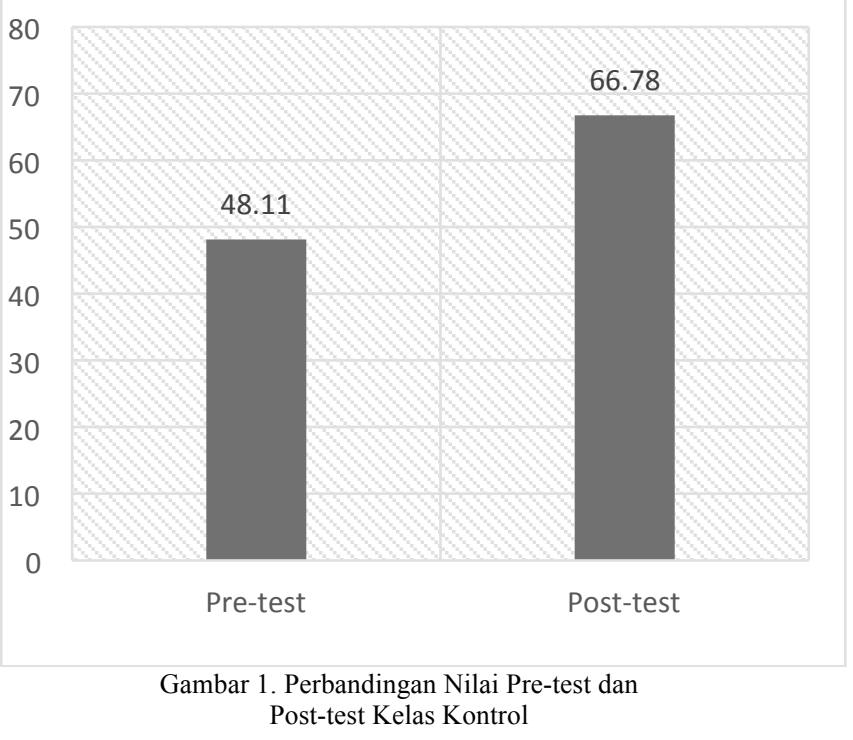

Dilihat dari Gambar di atas menunjukan bahwa rata-rata nilai hasil belajar siswa kelas kontrol dalam pelajaran TIK dengan materi ajar Microsoft Excel sebelum menggunakan model pembelajaran konvesional adalah 48,11 dan sesudah menggunakan model pembelajaran konvesional adalah 66,78. Dari data tersebut maka diperoleh kesimpulan bahwa nilai rata-rata hasil belajar siswa kelas eksperimen tersebut mengalami peningkatan sebesar 18,67 .

\section{Hasil Pretes, Postes dan peningkatan Hasil Belajar Kelas Eksperimen}

Dari hasil penelitian diperoleh data skor hasil pre-test, post-tes, dan peningkatan hasil belajar siswa kelas Eksperimen. Setelah dilakukan analisis terhadap hasil belajar siswa baik sebelum maupun setelah dilakukan proses pembelajaran Berbasis komputer dengan model tutorial, selanjutnya untuk mengetahui peningkatan hasil belajar dilakukan dengan menghitung nilai gain ternormalisasi. 


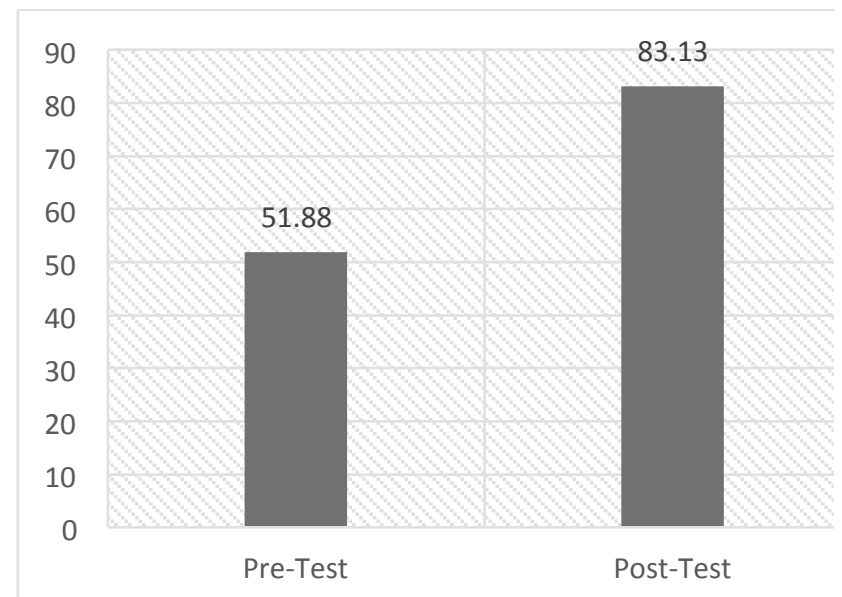

Gambar 2. Perbandingan Nilai Pre-test dan Post-test Kelas eksperiment

Dilihat dari Gambar 2 menunjukan bahwa rata-rata nilai hasil belajar siswa kelas kontrol dalam pelajaran TIK dengan materi ajar Microsoft Excel sebelum menggunakan model pembelajaran Berbasis komputer dengan model tutorial adalah 51,88 dan sesudah menggunakan model pembelajaran Berbasis komputer dengan model tutorial adalah 83,13. Dari data tersebut maka diperoleh kesimpulan bahwa nilai rata-rata hasil belajar siswa kelas eksperimen tersebut mengalami peningkatan sebesar 31,26.

\section{Perbandingan Peningkatan Hasil Belajar Siswa Kelas Eksperimen Kelas Kontrol.}

Ringkasan data statistik peningkatan hasil belajar siswa dalam aspek kognitif yaitu ingatan (C1), pemahaman (C2) dan penerapan (C3). Dapat diketahui dengan jumlah subjek kelas eksperimen 30 orang dan kelas kontrol 30 orang. Perbandingan nilai rata-rata Pre-Test peningkatan hasil belajar siswa dalam aspek kognitif yaitu ingatan $(\mathrm{C} 1)$, pemahaman $(\mathrm{C} 2)$, dan penerapan (C3), mengenai materi microsoft excel antara kelas kontrol dengan kelas eksperimen adalah 66,78:83,13, jadi perbandingan rata-ratanya adalah 16,35. Perbandingan gain skor antara kelas kontrol dengan kelas eksperimen adalah 18,67 : 31,26. Sedangkan, perbandingan Gain ternormalisasi antara kelas kontrol dengan kelas eksperimen adalah 0,35:0,65 dan standar deviasi peningkatan hasil belajar siswa dalam aspek kognitif yaitu ingatan (C1), pemahaman (C2), dan penerapan (C3), mengenai materi microsoft excel kelas kontrol adalah 9,60 dan kelas eksperimen adalah 9,93.

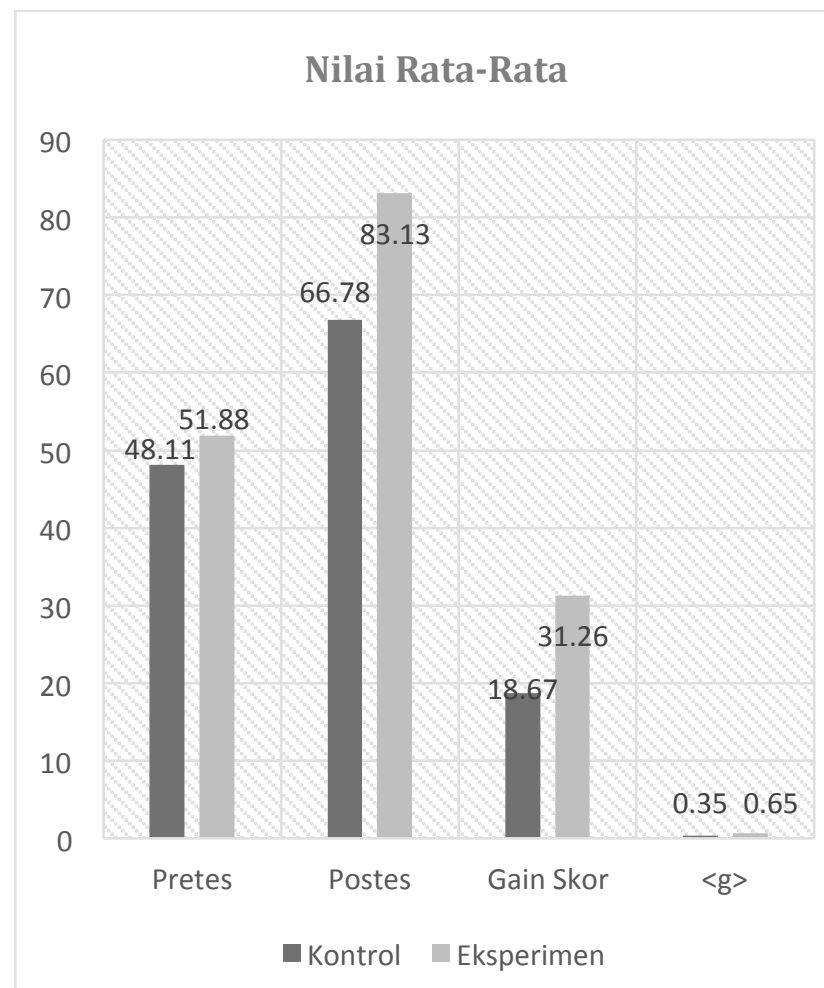

D. Analisis Data Kualitatif

\section{Uji Normalitas}

Dari hasil gain yng diperoleh oleh kelas kontrol dan kelas eksperimen, tahap pengujian statistik pertama yaitu melakukan uji normalitas sebaran data kedua kelas penelitian. Perhitungan pengujian normalitas menggunakan uji Chi Kudrat.

Dengan mengkonsultasikan $\chi_{\text {hitung }}^{2}$ pada $\chi_{\text {tabel }}^{2}$ pada taraf signifikansi 0,05 atau interval kepercayaan $95 \%$ diperoleh $\chi_{\text {hitung }}^{2}<\chi_{\text {tabel, }}^{2}$, sehingga dapat disimpulkan bahwa kelas kontrol dan kelas eksperimen berdistribusi normal

TABEL II

HASIL UJI NORMALITAS DATA GAIN

\begin{tabular}{|c|c|c|c|}
\hline $\begin{array}{l}\text { Data yang } \\
\text { diuji }\end{array}$ & $\chi_{\text {hitung }}^{2}$ & $\begin{array}{l}\chi_{\text {tabel }}^{2} \\
X_{0,95(3)}^{2}\end{array}$ & Kesimpulan \\
\hline Kontrol & 2,41 & 7.82 & Normal \\
\hline Eksperimen & 5,49 & 7.82 & Normal \\
\hline
\end{tabular}

Uji Homogenitas

Menurut statistik, jika memiliki $F_{\text {hitung }}$ lebih besar dari $F_{\text {tabel }}$ yang dipakai oleh peneliti pada taraf kepercayaan 95\% dan 99\%, sebuah sampel dapat dikatakan homogen. Hasil uji homogenitas yang dilakukan terhadap kelas kontrol dan kelas eksperimen yang diteliti adalah : 
Dengan mengkonsultasikan $F_{\text {hitung pada }} F_{\text {tabel }}$ pada taraf signifikansi 0,05 atau interval kepercayaan 95\% dan signifikansi 0,001 atau interval kepercayaan 99\%, diperoleh bahwa $F_{\text {hitung }}<F_{\text {tabel }}$, sehingga dapat disimpulkan bahwa kelas kontrol dan kelas eksperimen adalah sampel yang homogen.

TABEL III

HASIL UJI HOMOGENITAS DATA GAIN

\begin{tabular}{|l|l|l|l|l|}
\hline $\begin{array}{l}\text { Data yang } \\
\text { diuji }\end{array}$ & $\mathbf{F}_{\text {hitung }}$ & $\begin{array}{l}\text { F } \\
(\mathbf{3 0 , 2 4 )}\end{array}$ & $\begin{array}{l}\mathbf{F} \\
\mathbf{( 3 0 , 2 4 )}\end{array}$ & $\begin{array}{l}\text { Kesimpul } \\
\text { an }\end{array}$ \\
\hline $\begin{array}{l}\text { Kontrol } \\
\text { Eksperimen }\end{array}$ & 0,94 & 1.84 & 2.39 & Homogen \\
\hline
\end{tabular}

Uji Hipotesis

Menurut statistik, jika memiliki $t_{\text {hitung lebih besar dari }}$

$t_{\text {tabel }}$ yang dipakai oleh peneliti pada taraf kepercayaan $95 \%$ dan $\mathrm{v}=29, \mathrm{H}_{0}$ ditolak dan $\mathrm{H}_{1}$ diterima. Pengujian hipotesis dapat dilakukan dengan melihat tabel distribusi $\mathrm{t}$, harga $\mathrm{t}$ yang diperoleh kemudian dikonsultasikan. Hasil uji hipotesis yang dilakukan terhadap kelas kontrol dan eksperimen yang diteliti adalah sebagai berikut:

Dengan mengkonsultasikan $t_{\text {hitung }}$ pada $t_{\text {tabel }}$ pada taraf signifikansi 0,05 atau interval kepercayaan 95\% dan $\mathrm{v}=$ 29 , diperoleh bahwa $t_{\text {hitung }}>t_{\text {Tabel }}$ yang berarti $\mathrm{H}_{0}$ ditolak dan $\mathrm{H}_{1}$ diterima. Kesimpulan yang dapat diperoleh dari hasil uji-t ini adalah bahwa penggunaan model pembelajaran Berbasis Komputer dengan Model Tutorial secara signifikan dapat lebih meningkatkan hasil belajar siswa dalam aspek kognitif yaitu pengetahuan (C-1) dan pemahaman (C-2) mengenai materi Excel dibandingkan dengan menggunakan pembelajaran konvensional.

TABEL IV

HASIL UJI HIPOTESIS DATA GAIN

\begin{tabular}{|l|l|l|l|}
\hline Data yang diuji & $\mathbf{t}_{\text {hitung }}$ & $\mathbf{t}_{\mathbf{0 . 9 5}(\mathbf{2 9})}$ & \multicolumn{1}{|c|}{ Kesimpulan } \\
\hline $\begin{array}{l}\text { Kontrol } \\
\text { Eksperimen }\end{array}$ & 5,043 & 1,6973 & $\begin{array}{l}\mathrm{H}_{0} \text { ditolak dan } \mathrm{H}_{1} \\
\text { diterima }\end{array}$ \\
\hline
\end{tabular}

\section{E. Analisis Data Skala Sikap (Angket)}

Angket ini diberikan kepada kelas eksperimen dan digunakan untuk menelaah sikap siswa terhadap pembelajaran TIK dengan Berbantu media berbasis tutorial. Peneliti membuat angket tertulis yang terdiri dari 30 pertanyaan. Pada penelitian ini, peneliti membahas mengenai interprestasi skala sikap siswa secara umum. Analisis selengkapnya untuk lampiran sikap siswa dapat dilihat pada lampiran D dalam perhitungan setiap interprestasi terlebih dahulu kita harus menentukan nilai maksimum, nilai minimum, rentang, panjang kelas dan skala tanggapan.

\section{Interprestasi Skala Sikap Secara Umum Siswa Kelas Eksperimen}

Pada skala sikap diperoleh nilai maksimum 4500, nilai minimum 1800, rentang 2700 dan panjang kelas 540 sehingga didapat skala tanggapan. Skala tanggapan bisa dilihat pada lampiran F. Rekapitulasi Interprestasi sikap siswa terhadap pembelajaran berbasis komputer termasuk interprestasi Baik karena skor total yang di dapat adalah 3970 .

\section{F. Pembahasan}

Pengaruh PembelajaranKonvensional Terhadap Hasil Belajar siswa.

Penelitian dilaksanakan sebanyak 3 kali pertemuan di kelas kontrol (VIII-F). Pada saat pertemuan pertama dilakukan dulu Pretes atau tes awal unuk mengetahui kondisi pemahaman awal siswa pada kelas kontrol dengan hasil analisi data Pretes yaitu memperoleh nilai rata-rata 48,11. Pada pertemuan kedua sampai pertemuan ketiga setelah di lakukan pretes kelas kontrol di berikan perlakuan dengan menggunakan metode pembelajaran konvensional atau ceramah yang menjelaskan tentang lingkungan hidup siswa cukup antusias dalam memperhatikan pelajaran. Djamarah (Kholik, 2011), metode pembelajaran konvensional adalah metode pembelajaran tradisional atau disebut juga dengan metode ceramah, karena sejak dulu metode ini telah dipergunakan sebagai alat komunikasi lisan antara guru dengan anak didik dalam proses belajar dan pembelajaran. Dalam pembelajaran sejarah metode konvensional ditandai dengan ceramah yang diiringi dengan penjelasan, serta pembagian tugas dan latihan.

\section{G. Pengaruh Media Pembelajaran Berbasis Komputer dengan Model Tutorial Terhadap Hasil Belajar Siswa.} Pembelajaran menggunakan pembelajaran berbasis komputer dengan model tutorial guru sebagai fasilitator dan motivator yang menuntun dan membimbing siswa agar lebih aktif dan analis serta tidak hanya berinteraksi dengan guru sebagai salah satu sumber belajar, tetapi berinteraksi dengan keseluruhan sumber belajar yang dipakai untuk mencapai pembelajaran. Pembelajaran berbasis komputer dengan model tutorial merangsanng pengembangan kemampuan berfikir siswa secara kreatif dan menyeluruh, karena dalam proses belajarnya, siswa banyak melakukan memperhatikan dan mengingat isi materi tersebut. Berdasarkan penelitian yang dilakukan di SMPN 1 Cisurupan mengenai penggunaan media pembelajaran berbasis komputer dengan model tutorial pada mata pelajaran tik khususnya materi excel di rasa sangat cukup membantu siswa dalam memahami materi yang di pelajari, hal ini dapat dilihat dari respon siswa terhadap media pembelajaran berbasis komputer dengan model tutorial yaitu nilai rata-rata pretes dan postes kelas kontrol yaitu 31,26 dilihat dari gain skornya.yang 
termasuk kedalam kategori berkontribusi sebagian besar dengan kata lain sangat membantu peserta didik dalam memahami materi.

H. Perbandingan Pengaruh Hasil Belajar Siswa Kelas Vlll Yang Menggunakan Model Tutorial Dengan Pembelajaran Berbasis Komputer Dengan Siswa Yang Menggunakan Pembelajaran Konvensional.

Berdasarkan hasil penelitian ini menunjukkan bahwa pembelajaran berbasis komputer dengan model tutorial dapat meningkatkan hasil belajar siswa. Hal ini terbukti dengan nilai rata-rata untuk kelas eksperimen mencapai 83, sedangkan nilai untuk kelas kontrol mencapai 66 kriteria ketuntasan mata pelajaran (KKM) yang ditargetkan yaitu nilai mata pelajaran tik minimal harus mencapai 70. Hal tersebut menunjukkan bahwa rata-rata kelas yang dikenai pembelajaran berbasis komputer dengan model tutorial lebih tinggi dari pada kelas yang dikenai metode pembelajaran konvensional. Hal tersebut sesuai Riasat Ali (2008) dalam penelitian menyimpulkan bahwa nilai rata-rata kelompok eksperimen lebih tinggi dibandingkan dengan nilai rata-rata kelompok kontrol. Penggunakan pembelajaran berbasis komputer dengan model tutorial lebih baik dalam meningkatkan hasil belajar siswa kelas VIII SMPN 1 Cisurupan Serta mendukung pendapat penelitian sebelumnya Riasat Ali (2008) dalam penelitian menyimpulkan bahwa nilai ratarata kelompok eksperimen lebih tinggi dibandingkan dengan nilai rata-rata kelompok kontrol. Secara keseluruhan penggunaan metode pembelajaran berbasis komputer dengan model tutorial lebih baik dalam meningkatkan hasil belajar siswa.

\section{KESIMPULAN}

Berdasarkan data dan hasil analisis penelitian yang telah dilakukan tentang pembelajaran berbasis komputer dengan model tutorial pada mata pelajaran TIK di kelas VIII C dan VIII F dapat di simpulkan bahwa :

1. Model pembelajaran yang dilakukan secara konvesional juga dapat mempengaruhi hasil belajar siswa walaupun yang di peroleh tidak sebesar yang diberikan perlakuan dengan menggunakan pembelajaran berbasis komputer dengan model tutorial.

2. Untuk Model pembelajaran Berbasis Komputer dengan model tutorial ternyata dapat mempengaruhi hasil belajar siswa dari yang ratarata sebelum diberikan perlakuan yaitu 70 dan setelah diberikan perlakuan bisa mencapai 83.13.

3. Dari data tersebut bahwa pembelajaran yang menggunakan pembelajaran berbasis komputer dengan model tutorial lebih baik dari pada pembelajaran yang secara konvensional.

4. Pada skala sikap diperoleh nilai maksimum 4500, nilai minimum 1800, rentang 2700 dan panjang kelas 540 sehingga Rekapitulasi Interprestasi Sikap Secara Umum Siswa Kelas Eksperimen adalah 3970 terdapat Interprestasi BAIK.

\section{DAFTAR PUSTAKA}

[1] Sundayana, Rumus Alpha. Bandung: Alfabeta, 2015, p. 69.

[2] Sudjana, N dan Ahmad Rivai, Pengertian Pembelajaran.

[3] Daryanto, Pengertian pembelajaran menurut paradigma behavioristik. Jakarta: Kencana, 2010, p. 2.

[4] Arsyad, A,. Jakarta: Rineka Cipta, 2011, p. 1.

[5] Arief S. Sadiman, dkk, Media Pendidikan : Pengertian, Pengembangan, dan Pemanfaatannya. Jakarta: Rajawali Press, 2009.

[6] Daryanto, Media Pembelajaran. Jakarta: Rineka Cipta, 2010, p. 4.

[7] Darmawan, D, Teknologi Pembelajaran. Bandung: PT Remaja Rosdakarya, 2011, p. 32.

[8] Benny A, dkk, " ," in Kelebihan Pembeljaran berbasis komputer. Jakarta: Erlangga, 2002, pp. 11-13.

[9] Sudjana, N, Pengertian Hasil Belajar. Bandung: Alfabeta, 2011, p. 22.

[10] Tabrani Rusyan, dkk, Pengertian Hasil Belajar. Jakarta: Kencana, 1994, p. 79.

[11] Bloom, Klasifikasi Bloom Ranah Kognitif Beserta Contoh C1-C6. Bandung: Alfabeta, 2013. 